Jurnal ABDIMAS INDEPENDEN

Vol. 1, No. 2, November 2020

\title{
PENANGGULANGAN KEMISKINAN MELALUI PELATIHAN DAN PEMBINAAN KEWIRAUSAHAAN UKM BIDANG PARIWISATA DI KAWASAN PESISIR PANTAI CEMARA LEMBAR KABUPATEN LOMBOK BARAT
}

\author{
Masrun $^{1}$, Akhmad Jufri $^{2}$, Titi Yuniarti ${ }^{3}$, Firmansyah ${ }^{4}$, Suprianto ${ }^{5}$ \\ Jurusan Ilmu Ekonomi dan Studi Pembangunan - Universitas Mataram \\ masrun.feunram@yahoo.com
}

\begin{abstract}
ABSTRAK
Pelatihan yang dilaksanakan ini merupakan wujud dari pelaksanaan Tri dharma Perguruan Tinggi yang berupa pengabdian pada masyarakat, dengan tema "Penanggulangan Kemiskinan Melalui Pelatihan Dan Pembinaan Kewirausahaan UKM Bidang Pariwisata Di Kawasan Pesisir Pantai Cemara Lembar Kabupaten Lombok Barat". Adapun tujuan kegiatan pelatihan dan pembinaan adalah membantu mengembangkan kemampuan pengusaha kecil mikro yang meliputi: membangun motivasi untuk berusaha, meningkatkan akses pasar dan menyiapkan masyarakat usaha kecil untuk menyesuikan diri dengan perubahanperubahan lingkungan yang cepat dan tidak pasti. Metode yang digunakan dalam pelatihan ini adalah melalui metode: ceramah untuk menyampaikan materi yang telah ditentukan, Tanya jawab/diskusi dan setelah pelatiahanpeserta akan dibina oleh tim pelaksana pengabdian. Berdasarkan hasil pengamatan selama pelatihan berlangsung, hampir seluruh peserta yang hadirmemberikan tanggapan positif (baik) pada materi pelatihan. Dengan melalui pelatihan dan pembinaan, peserta telah membawa perubahan yang meningkat, walaupun tidak signifikan dari kondisi sebelum dengan sesudahnya. Dari kondisi hasil tersebut, maka dapat direkomendasikan hal penting yaitu peserta pelatihan ini diharapkan ditindaklanjuti dengan kegiatan pendampingan, pemagangan dan studi banding ditempat pengusaha/perusahaan yang sukses.
\end{abstract}

Kata Kunci :Kemiskinan, UKM dan Pariwisata 


\begin{abstract}
This training carried out a manifestation of the implementation of the Tridharma of Higher Education in the form of community service, the theme is "Poverty Alleviation through Training and Development of Entrepreneurship for Tourism in Coastal Areas of Cemara Lembar, West Lombok Regency." The purpose of this research is to train micro-small entrepreneurs which includes: build a motivation in business, increase market access and prepare the small business community to adapt the uncertain environment. The method used in this training: speech to convey materials, question and answer, participants will be fostered by the community service implementation team. According to the observation during the training, almost all participants who attend the training gave a positive (good) responses to the training materials. Through training and coaching, participants show increasing knowledge, even though insignificant from the conditions before. Based on the results concluded that the important thing is the participants in this training are expected to be followed up with assistance, apprenticeship and comparative studies at successful entrepreneurs / companies.
\end{abstract}

Keywords: Poverty, UKM and Tourism

\title{
PENDAHALUAN
}

Sumberdaya pesisir dan laut memberikan sumbangan yang sangat penting bagi perekonomian Indonesia, namun hingga kini pemanfaatannya belum memenuhi pemanfaatan berkelanjutan. Pemanfaatan yang dilakukan cenderung menyebabkan terjadinya kerusakan ekosistem dan kepunahan sumberdaya pesisir dan lautan. Tekanan terhadap sumberdaya pesisir dan laut semakin memburuk dalam situasi krisis ekonomi akibat terbatasnya alternatif mata pencaharian masyarakat pesisir, eksploitasi menjadi jalan pintas untuk tetap mempertahankan asap dapur rumah tangga nelayan pada umumnya. Beberapa factor yang menyebabkan kondisi tersebut (Purnomowati, R, 2004) adalah : (a) kurangnya pendekatan terpadu dalam perencanaan dan pengelolaan wilayah pesisir, (b) kurangnya data dan informasi sebagai dasar pertimbangan dalam pengambilan kebijakan pengelolaan, (c) transparansi dalam pengalokasian 


\section{Jurnal ABDIMAS INDEPENDEN}

Vol. 1, No. 2, November 2020

pemanfaatan sumberdaya alam, (d) kurangnya kapasitas pemerintah daerah dalam perencanaan dan pengelolaan sumberdaya secara berkelanjutan dan (e) kurangnya pelibatan masyarakat lokal dalam perencanaan dan pengelolaan sumberdaya wilayah pesisir.

Kerusakan ini mengakibatkan nelayan harus pergi melaut untuk menangkap ikan semakin jauh dan semakin lama. Kondisi ini menambah beban berat kepada keluarga yang ditinggalkannya. Dapat dikatakan bahwa kaum wanitalah yang pertama-tama akan merasakan dampak dari adanya masalah lingkungan hidup.

Dalam rangka mengantisipasi keadaan tersebut, maka perlu diupayakan program pengembangan Masyarakat pesisir dan Nelayan kecil (Marginal Fishing Community Development Pilot /MFCDP) pada hakekatnya merupakan program pemberdayaan masyarakat pesisir dan nelayan kecil, dimana selama ini mereka merupakan salah satu kelompok masyarakat yang terpinggirkan. Program ini menitik beratkan pada keterlibatan masyarakat pesisir dan nelayan kecil dalam mengelola kawasan pesisir, peningkatan aktifitas dari proses perencanaan dan membantu memecahkan masalah-masalah pengelolaan kawasan pesisir serta mengembangkan kegiatan perekonomian dengan memberikan kesempatan penuh dalam pengembangan usaha (Bappenas, 2004).

Kemiskinan adalah masalah struktural, maka upaya untuk mengatasi kemiskinan dikaitkan dengan perbaikan sistem dan struktur, tidak semata-mata bertumpu pada aksi sesaat berupa crash program. Sebuah upaya yang dapat dikembangkan adalah melalui konsep pembinaan sikap mental wirausaha pengusaha UKM. Kucuran dana dan modal saja tidak cukup, pembukaan kesempatan kerja juga belum tentu memperdayakan, bahkan bisa menimbulkan ketergantungan. Namun disisi lain, penanganan kemiskinan secara sporadis, tanpa desain atau skema penanggulangan terpadu yang jelas indikator pencapaiannya, juga dapat menggagalkan upaya mengeluarkan orang dari lingkaran kemiskinan (Achmad E, dkk, 2011) 
Pengembangan Usaha Kecil menjadi suatu hal yang krusial mengingat Usaha Kecil mempunyai peranan yang demikian penting untuk pertumbuhan ekonomi sebuah negara termasuk dinegara Indonesia (Tambunan, 2005). Ini, menunjukkan bahwa Usaha Kecil mempunyai kemampuan untuk memperkuat struktur perekonomian nasional Meskipun secara ekonomi UKM mempunyai kontribusi yang signifikan terhadap pertumbuhan ekonomi, namun dalam pengembangannya menghadapi berbagai permasalahan. Menurut Winarni (2006) dan Situmorang (2008) permasalahan yang dihadapi Usaha Kecil adalah (a) kurang permodalan, (b) kesulitan dalam pemasaran, (c) struktur organisasi sederhana dengan pembangian kerja yang tidak baku, (d) kualitas manajemen rendah, (e) kebanyakan tidak mempunyai laporan keuangan, (f) SDM terbatas dan kualitasnya rendah, (g) aspek legalitas lemah (h) rendahnya kualitas teknologi.

Kondisi ini mengakibatkan lemahnya jaringan usaha, keterbatasan kemampuan penetrasi pasar dan diversifikasi pasar, skala ekonomi terlalu kecil sehingga sukar menekan biaya, margin keuntungan sangat kecil dan lebih jauh lagi Usaha Kecil tidak memiliki keunggulan kompetitif. Melihat berbagai permasalahan yang dihadapi dalam pengembangan Usaha Kecil, maka dibutuhkan suatu model pemberdayaan UKM untuk dapat berjalan dengan cepat, permasalahan yang dihadapi UKM dapat direduksi dan UKM mempunyai keunggulan kompetitif (Hafsah, 2004).

Sesuai dengan sifat dasarnya produk-produk perikanan sangat tergantung pada musim. Saat musim panen, hasil tangkapan dan produk nelayan sangat berlimpah dan sebaliknya pada saat paceklik produknya sangat terbatas atau bahkan tidak ada sama sekali. Selain itu, karena produk perikanan diwilayah pesisir dan laut juga tidak tahan lama, sehingga upaya peningkatan keterampilan terkait dengan teknik penanganan pasca panen harus dilakukan. Menurut (Eddy, A, dkk, 2008) bahwa hasil tangkapan maupun hasil budidaya ikan/udang dipantai Cemara kecamatan Lembar kabupaten Lombok Barat cukup tinggi dengan jenis 


\section{Jurnal ABDIMAS INDEPENDEN}

Vol. 1, No. 2, November 2020

ikan yang ditangkap maupun yang dibudidayakan diantaranya ikan bandeng, udang, kepiting karang dan udang kecil (rebon).

Kondisi yang dialami kawasan pesisir Pantai Cemara Lembar, dari informasi yang diperoleh, pengusaha kecil selain sebagai jasa penyedia perahu, motor boat, pohon mangrove (bakau) dan juga berprofesi sebagai pedagang pengumpul, pedagang bakulan, usaha kios serta usaha lain-lain dibidang pariwisata. Kondisi umum pengusaha kecil di kawasan pesisir Pantai Cemara Lembar dari sisi manajemen kewirausahaannya masi lemah/kurang.

Masalah umum yang dialami pengusaha kecil mikro dikawasan pesisir Pantai Cemara Lembar Kabupaten Lombok Barat yang perlu dicarikan solusinya, antara lain :

1. Tidak mempunyai kemampuan manajerial

2. Tidak memiliki rencana usaha

3. Etos kerja rendah

4. Informasi dan akses terbatas

5. Tidak memiliki catatan administrasi usaha yang memadai

6. Pemasaran produk yang lemah

7. Kurang dapat mengendalikan keuangan

8. Kemampuan daya tawar dan negosiasi yang terbatas

9. Tidak memiliki wawasan bisnis

Untuk memecahkan permasalahan yang dihadapi masyarakat dapat dilakukan dengan meningkatkan pengetahuan/ketrampilan melalaui kegiatan pelatihan motivasi kewirausahaan. Kegiatan ini merupakan alternatif untuk merubah kondisi ekonominya dan sebagai upaya untuk meningkatkan kesejahteran masyarakat. Dalam pelatihan tersebut, selain tutor memberikan materi motivasi kewirausahaan, juga dilakukan tanya jawab/diskusi. Pada diskusi ini, masyarakat peserta pelatihan dapat menyampaikan kondisi permasalahan yang dihadapi dalam usaha yang dijalankan selama ini. 
Usaha yang akan dikembangkan pada suatu kawasan pesisir Pantai Cemara Lembar Kabupaten Lombok Barat akan disesuaikan dengan potensi sumber daya dan kebutuhan masyarakat, kepada masyarakat sasaran akan diberikan pelatihan.

Indikator capaian yang diharapkan melalui pembinaan wirausaha UKM ini dapat membawa perubahan peningkatan keterampilan pengusaha kecil secara signifikan dan terukur pada tabel berikut ini:

Tabel 1: Indikator Capaian

\begin{tabular}{|c|c|c|c|}
\hline No & Kegiatan & Kondisi Sebelum & Kondisi Sesudah \\
\hline 1 & $\begin{array}{l}\text { Pengelolaan } \\
\text { usaha }\end{array}$ & $\begin{array}{l}\text { - } \quad \text {-Tidak memiliki rencana } \\
\text { usaha } \\
\text { - } \quad \text { Belum terampil } \\
\text { pencatatan dan laporan } \\
\text { keuangan } \\
\text { - } \quad \text { Kemampuan pendekatan } \\
\text { dan negosiasi rendah }\end{array}$ & $\begin{array}{l}\text { - } \quad \text { Memiliki rencana usaha } \\
\text { - } \text { perampil dalam } \\
\text { keuangan } \\
\text { - } \quad \text { Mempunyai kemampuan } \\
\text { pendekatan dan terampil } \\
\text { dalam negosiasi }\end{array}$ \\
\hline 2 & $\begin{array}{l}\text { Penguasaan } \\
\text { pasar }\end{array}$ & $\begin{array}{ll}\text { - } & \text { Segmen pasar terbatas } \\
\text { - } & \text { Belum ada kerja sama } \\
& \text { dengan pihak lain } \\
\end{array}$ & $\begin{array}{ll}\text { - } & \text { Segmen pasar luas } \\
\text { - } & \text { Adanya kerja sama } \\
& \text { dengan pihak lain } \\
\end{array}$ \\
\hline 3 & $\begin{array}{l}\text { Penanganan } \\
\text { produk/ } \\
\text { produksi }\end{array}$ & $\begin{array}{l}\text { - } \text { Memiliki peralatan manual } \\
\text { / sederhana } \\
\text { - } \quad \text { Penanganan produk } \\
\text { memenuhi standar }\end{array}$ & $\begin{array}{l}\text { - } \text { Memiliki peralatan semi } \\
\text { modern } \\
\text { - } \quad \text { Penanganan produk } \\
\text { sesuai memenuhi } \\
\text { standar }\end{array}$ \\
\hline 4 & Etos kerja & $\begin{array}{ll}\text { - } & \text { Kurang disiplin kerja } \\
\text { - } & \text { Kurang semangat kerja } \\
\text { - } & \text { Kurang percaya diri dan } \\
& \text { optimism } \\
\text { - } & \text { Kurang beroriantasi pada } \\
& \text { laba /hasil } \\
\text { - } & \text { Kurang inisiatif dan } \\
& \text { kreatif }\end{array}$ & $\begin{array}{l}\text { - } \quad \text { Adanya disiplin kerja } \\
\text { - } \quad \text { Tinggi semangat kerja } \\
\text { - } \quad \text { Percaya diri dan } \\
\text { optimis } \\
\text { - } \quad \text { Beroriantasi pada } \\
\text { laba/ hasil } \\
\text { - } \quad \text { Berinisiatif dan kreatif }\end{array}$ \\
\hline
\end{tabular}

Tujuan kegiatan adalah membantu mengembangkan kemampuan pengusaha kecil mikro melalui pelatihan kewirausahaan yang meliputi :

1. Membangun sikap, mentalitas dan motivasi untuk berusaha

2. Meningkatkan keterampilan pengelolaan usaha

3. Meningkatkan wawasan bisnis 


\title{
Jurnal ABDIMAS INDEPENDEN
}

\author{
Vol. 1, No. 2, November 2020
}

4. Meningkatkan penguasaan akses pasar

5. Menyiapkan pengusaha kecil mikro untuk menyesuaikan diri dengan perubahan-perubahan lingkungan yang cepat dan tidak pasti

\section{METODE KEGIATAN}

Metode yang digunakan dalam pelatihan ini adalah melalui :

1. Ceramah untuk menyampaikan materi-materi yang telah ditentukan

2. Tanya jawab/diskusi

3. Pada akhir pelatihan, peserta dibagikan isian untuk memperoleh umpan balik tentang : (a) materi pelatihan yang diberikan oleh tim. (b) system/metode yang digunakan. (c) saran/masukan untuk tim pelaksana

Materi yang diberikan pada pelatihan tersebut, antara lain :

1. Kewirausahaan

2. Manajemen Pengelolaan Usaha

3. Manajemen Keuangan

4. Pemasaran Produk

5. Rencana Pendirian/Pengembangan Usaha

Kami dari Tim dengan jujur untuk tidak menyembunyikan bahwa diantara para peserta yang hadir ada yang sudah memahami tentang materi sebelum dilakukan pelatihan, tetapi sebagian besar peserta yang hadir masih belum memahami materi tersebut. Setelah diadakan pelatihan, para peserta akan dimbimbing oleh Tim untuk memberikan arahan yang terkait dengan pengelolaan usahanya.

Sebagai sasaran kegiatan pelatihan ini adalah pengusaha kecil mikro yang telah memenuhi kriteria ditentukan yang berada diwilayah kawasan pesisir Pantai Cemara Lembar Kabupaten Lombok Barat. Kriteria yang dimaksud adalah :

1. Memiliki usaha yang bergerak dibidang produksi dan perdagangan.

2. Memiliki pengalaman usaha 2 (dua) tahun. 
3. Mempunyai komitmen untuk ingin maju dan berkembang.

Selanjutnya dalam mengidentifikasi peserta dengan beracuan pada kriteria tersebut di atas, maka ditetapkan/ditentukan peserta pelatihan sekaligus untuk dimbimbing sebanyak 20 orang

\section{HASIL DAN PEMBAHASAN}

\section{Pelatihan}

Ceramah yang disampaikan oleh Tim pengabdian pada masyarakat dengan materi pelatihan, rupanya seluruh peserta yang hadir memberikan tanggapan yang baik (positif). Ini terlihat dari beberapa peserta dengan antusias dalam diskusi (tanya jawab) dengan tutor (tim) selama pelatihan berlangsung.

\section{Bimbingan dan Evaluasi}

Selama kegiatan berlangsung tampak perhatian dan antusias peserta cukup tinggi, hal ini dapat dilihat pada saat ceramah/tatap muka dalam rangka penyampaian materi pelatihan berlangsung. Peserta pelatihan secara sungguhsungguh memperhatikan dan mengikutinya. Demikian juga pada saat diskusi berlangsung serta juga mengajukan berbagai pertanyaan yang berkaitan dengan penyampaian materi yang masih belum jelas.

Setelah selesai pelatihan para peserta ditindak lanjuti dengan bimbingan melalui tahapan antara lain :

1. Mengidentifikasi kondisi peserta

Yang diidentifikasi kondisi peserta adalah tentang usaha dan permasalahan yang dihadapinya. Usaha dari peserta setelah diidentifikasi ada 4 (empat), yaitu antara lain :

a).Usaha produksi hasil laut, b).Penangkapan ikan/nelayan, c).Pengepul ikan dan d).Usaha dagang. 


\section{Jurnal ABDIMAS INDEPENDEN}

Vol. 1, No. 2, November 2020

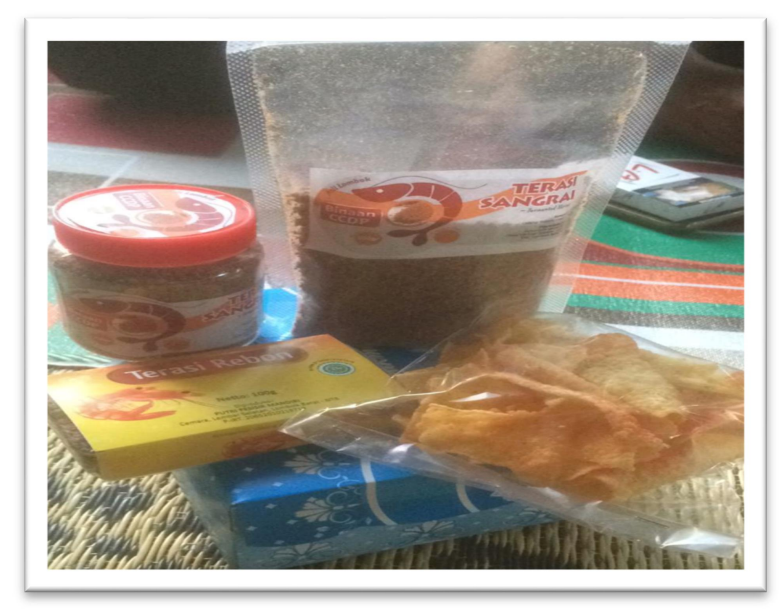

Gambar 1: Produk UKM di Pantai Cemara Lembar

Sedangkan masalah yang dihadapi oleh peserta dapat teridentifikasi sebagai berikut :

a).Kesulitan pemasaran, b).Kurang bimbingan dan pembinaan dari instansi terkait,, c).Harga jual rendah, d).Alat transportasi, e).Tingkat pendapatan yang tidak konsisten, f).Peralatan dan modal usaha dan g).Teknologi masih tradisional.

2. Mengevaluasi kegiatan Bimbingan

Berdasarkan hasil evaluasi terhadap 20 peserta bimbingan di kawasan pesisir Cemara Lembar, baik sebelum maupun setelah pelatihan motivasi kewirausahaan dapat diuraikan pada tabel berikut :

Tabel 2: Persentase rata-rata nilai motivasi kewirausahaan peserta bimbingan di Dusun Cemara Lembar

\begin{tabular}{|l|c|c|c|}
\hline Kategori & Sebelum (\%) & Sesudah (\%) & Perubahan (\%) \\
\hline Lemah sekali & 12,34 & 13,11 & 0,77 \\
Lemah & 17,19 & 18,34 & 1,15 \\
Sedang & 18,53 & 19,04 & 0,51 \\
Kuat & 2,10 & 2,16 & 0,06 \\
Kuat sekali & 1,56 & 1,56 & 0 \\
\hline
\end{tabular}
Tabel 2 di atas menunjukkan terdapat perbedaan/perubahan nilai

motivasi kewirausahaan bimbingan sebelum dan sesudah pelatihan dan pembimbingan oleh Tim pengabdian pada masyarakat di dusun Cemara Lembar. 
Sebelum adanya pelatihan dan pembimbingan nilai motivasi kewirausahaan peserta untuk kategori sangat kuat sebesar 1,56 persen, ternyata tidak menunjukkan perubahan yaitu tetap nilai skor yang sama setelah diadakan pelatihan dan pembimbingan. Sedangkan pada nilai motivasi kewirausahaan peserta yang tergolong kategori kuat, dimana sebelum pelatihan dan pembinaan rata-ratanya sebesar 2,10 persen, setelah pelatihan dan pembinaan hampir tidak mengalami perubahan, karena hanya memberikan skor sebesar 2,16 persen.

Bila kita melihat sebelum pelatihan dan pembinaan kategori sedang, lemah dan lemah sekali masing-masing skor 18,53 persen, 17,19 persen dan 12,34 persen, ketika diberikan pelatihan dan pembimbingan menunjukkan perubahan kenaikan yang tidak terlalu signifikan. Kenaikan yang dimaksud adalah masing-masing 19,04 persen, 18,34 persen dan 13,11 persen.

Dari hasil kajian ini menggambarkan bahwa perlakukan pelatihan dan pembimbingan yang diberikan pada 20 peserta tersebut menunjukkan perubahan, namun perubahan kenaikan yang relatif kecil (tidak signifikan). Namun demikian, kesimpulan pelatihan dan pembimbingan memberikan informasi yang sangat berharga untuk kegiatan lebih lanjut sehingga dapat dijadikan sebagai dasar penentuan kebijakan dimasa yang akan datang.

\section{a. Faktor Pendorong}

Sebagai faktor pendorong dalam kegiatan pengabdian pada masyarakat ini adalah berasal dari berbagai pihak, antara lain Lembaga Penelitian Dan Pengabdian Kepada Masyarakat (LPPM) Universitas Mataram yang menyetujui kegiatan pelatihan tersebut. Dari Kepala Dusun Cemara Lembar secara positif memberikan dukungan untuk terselenggaranya kegiatan, seperti memotivasi peserta pelatihan dan menyediakan tempat pelatihan.

\section{b. Faktor Penghambat}

Secara umum dari pelaksanaan kegiatan pengabdian ini sejak perencanaan sampai dilangsungkannya kegiatan baik pelatihan maupun 


\section{Jurnal ABDIMAS INDEPENDEN}

Vol. 1, No. 2, November 2020

pembimbingan, tidak memperoleh hambatan berarti. Namun demikian sebagai hambatan yang mungkin akan dapat mempengaruhi tercapainya tujuan adalah adanya istilah asing dalam materi pelatihan dan adanya persepsi bahwa kondisi harga yang terus naik, sehingga sulit untuk mengimbangi biaya operasional usahanya.

\section{SIMPULAN DAN SARAN}

\section{Simpulan}

1. Kegiatan peningkatan manajemen usaha kecil mikro melalui pelatihan kewirausahaan pada masyarakat pesisir, dapat memberikan wawasan tentang materi diberikan.

2. Melalui pelatihan dan pembimbingan, peserta telah membawa perubahan yang meningkat dari kondisi sebelum dengan sesudahnya.

\section{Saran}

1 Peranan bimbingan dari pihak yang terkait sangat dibutuhkan dalam upaya peningkatan pengelolaan usaha, pemasaran produk, manajemen keuangan dan rencana/pengembangan usaha secara berkesinambungan.

2 Bahwa kegiatan pelatihan dan pembimbingan sekarang, hanya sebagai awal dan akan berhasil dengan baik kalau dilaksanakan secara menyeluruh dan berkesinambungan.

\section{UCAPAN TERIMA KASIH}

Untuk dapat terlaksananya kegiatan pelatihan dan pembinaan/bimbingan ini, maka dari tim Pengabdian Pada Masyarakat Fakultas Ekonomi Dan Bisnis Universitas Mataram menyampaikan ucapan terima kasih kepada :

a. Lembaga Penelitian Dan Pengabdian Kepada Masyarakat (LPPM) Universitas Mataram, yang memberikan dana untuk menunjang 
dalam pelaksanaan pelatihan dan pembinaan terhadap masyarakat khlayak sasaran (UKM)

b. Kepala Dusun Kawasan Pesisir Cemara Lembar Kabupaten Lombok Barat berperan untuk mengidentifikasi masyarakat yang akan menjadi peserta dan menyediakan fasilitas pelaksanaan pelatihan.

c. Masyarakat khalayak sasaran yang berperan sebagai peserta pelatihan dan dibimbing oleh tim pengabdian.

\section{DAFTAR PUSTAKA}

Achmad, E, dkk, 2008, Analisis Ekonomi Ekologis Sumberdaya Pesisir Pantai Cemara Kabupaten Lombok Barat, Proyek Pengembangan Kapasitas Riptek Masyarakat Kementrian Riset dan Teknologi, Jakarta

Bappenas, 2004, Membangun Perikanan Menuju Abad ke 21, Jakarta

Hafsah, M.J, 2004, Upaya Pengembangan Usaha Kecil, Infokop, No. 25 Tahun XX

Purnomowati, R, 2004, Kebijakan dan Strategi Ekonomi Rakyat, BPFE, Yogyakarta

Sutomorang, J, 2008, Strategi Usaha Kecil Dalam Menghadapi Iklim Usaha, Infokop, Tahun XXIV

Tambunan, T, 2005, Usaha Kecil Di Indonesia : Beberapa Isu Penting, Salemba, Jakarta

Winarni, 2006, Strategi Pengembangan Usaha Kecil Melalui Peningkatan Aksesibilitas, Infokop, Tahun XXII 